\title{
Zinc Chloride Supplemented during Ovarian Tissue Vitrification Improves In Vitro Follicle Development and Fertilization in Pigs
}

EMMA C. HICKS, MEGAN MARTZ, HALEY A. ARENA, JUSTIN L. RHEUBERT, and BRIAN D. WHITAKER', University of Findlay, Findlay, OH, USA.

ABSTRACT. Ovarian tissue vitrification is a promising method to preserve follicles and gametes, but can be improved with mineral supplementation to the vitrification medium. The objective of this study was to determine the effects of supplementing $0.5 \mathrm{mg} / \mathrm{mL}$ zinc chloride to the media during cryopreservation of pig ovarian tissue. After thawing, the following criteria were evaluated: (1) follicular development and damage, (2) in vitro fertilization (IVF) characteristics, and (3) embryonic development. The number of damaged antral follicles $(72.0 \pm 3.8 \%)$ was less $(p<0.05)$ in ovarian tissue vitrified in media supplemented with zinc chloride compared to those not supplemented with zinc chloride $(86.7 \pm 4.1 \%)$. Oocytes obtained from the antral follicles on ovarian tissue vitrified in media supplemented with zinc chloride had less $(p<0.05)$ polyspermic penetration and higher $(p<0.05)$ male pronuclear formation during IVF than oocytes obtained from ovarian tissue not supplemented with zinc chloride. There were no statistical differences in embryonic development rates. Based on these results, supplementing zinc chloride during the vitrification protocol improves follicular development and subsequent IVF in pigs.

\section{INTRODUCTION}

There is a growing interest and need for cryopreservation techniques to be improved so that ovarian tissue and oocytes can be preserved in biomedical models and endangered species (Mouttham and Comizzoli 2016). Cryopreservation in the form of vitrification is a desirable type of preservation compared to other techniques, due to the ability of cryopreservation to preserve large numbers of oocytes at once. However, ovarian tissue is more susceptible to damage during vitrification since there are multiple cell types and levels of permeability within the tissue (Abedelahi et al. 2013). The cryoprotectant agents involved can induce oxidative stress which may lead to structural and functional changes in the tissue (Tian et al. 2015). In addition to tissue damage, the vitrification process increases the reactive oxygen species (ROS) in oocytes leading to reduced viability (Gupta et al. 2010).

Antioxidants help protect tissues from the damaging effects of oxidative stress by helping to maintain a more ideal level of ROS (Takahashi 2012). Antioxidants reduce risk of oxidative stress and lower ROS levels within a cell by converting

${ }^{1}$ Address correspondence to Brian D. Whitaker, University of Findlay, 1000 North Main St., Findlay, OH 45840, USA. Email: whitaker@findlay.edu
ROS to water (Agarwal et al. 2005). Zinc is an element present in the reproductive process that has antioxidant properties and is significant in maintaining ideal ROS levels (Murarka et al. 2015).

Zinc is a required mineral for the successful development, growth, and survival of mammalian embryos; it is often used as a supplement to treat female subfertility (Geravandi et al. 2017; Showell et al. 2017). Zinc chloride has antioxidant characteristics which help reduce ROS levels and prevent the damaging effects of oxidative stress (Geravandi et al. 2017). Studies have shown that zinc supplementation in the vitrification medium for mouse ovary vitrification increases the percentage of morphologically normal follicles in the tissue while also improving the viability of the oocytes within the tissue (Geravandi and Azadbakht 2017).

The authors are unaware of any reports supplementing zinc to the vitrification media in pigs (Sus scrofa). The objective of this study was to improve follicle cryopreservation and subsequent in vitro embryo production in pigs by determining the effects of zinc chloride supplementation to the ovary equilibration and vitrification media.

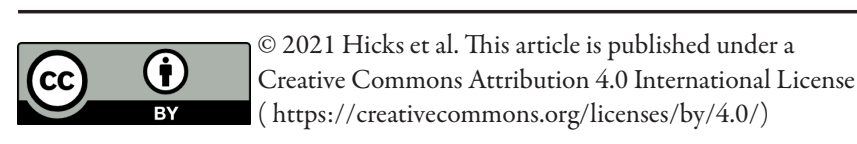


Following cryopreservation and thawing, follicular development and damage were evaluated. Oocytes were then matured, fertilized, and evaluated for penetration, polyspermic penetration, and male pronucleus (MPN) formation to determine in vitro fertilization (IVF) effectiveness. Embryos were evaluated for cleavage and blastocyst formation.

\section{METHODS AND MATERIALS}

\section{Media}

Unless otherwise stated, all chemicals were purchased from Sigma-Aldrich ${ }^{\circledR}$ Inc. (St. Louis, Missouri, USA). The equilibration solution was 7.5\% ethylene glycol (v/v), 7.5\% dimethyl sulfoxide (v/v), and $20 \%$ fetal calf serum (v/v) in HEPESbuffered Ham's F-10. The vitrification solution was $15 \%$ ethylene glycol (v/v), 15\% dimethyl sulfoxide (v/v), $0.5 \mathrm{M}$ sucrose, and $20 \%$ fetal calf serum (v/v) in HEPES-buffered Ham's F-10. The oocyte maturation media, based on Medium 199 (M199), was formulated by Yuan et al. (2017) and supplemented with $1 \mu \mathrm{g} / \mathrm{mL}$ insulin, $25 \mu \mathrm{g} / \mathrm{mL}$ gentamicin sulfate, $0.01 \mathrm{mM}$ glucuronic acid, 0.01 mM N-acetyl-D-glucosamine, and $10 \%$ porcine follicular fluid (v/v) (Schmidt et al. 2015). Porcine fertilization medium (Cosmo Bio USA, Carlsbad, California, USA) was used as the IVF media and a porcine embryo development medium (PZM-5) (Cosmo Bio USA) containing $0.4 \%(\mathrm{w} / \mathrm{v})$ bovine serum albumin (BSA) was utilized as the embryo culture medium.

All media were filtered through a $0.22 \mu \mathrm{m}$ pore mixed cellulose esters membrane syringe filter (Fisher Scientific ${ }^{\circledR}$ Co. LLC, Pittsburgh, Pennsylvania, USA). All incubations were carried out in media droplets under mineral oil at $38.5^{\circ} \mathrm{C}$ in a humid atmosphere of $5 \% \mathrm{CO}_{2}$ unless otherwise indicated.

\section{Vitrification of Ovarian Tissue}

Ovaries were obtained and pooled from adult crossbred gilts $(\mathrm{n}=100)$ (at least 18 months of age) at an abattoir. The average elapsed time between ovary collection and processing was $2 \mathrm{~h}$. Strips of ovarian cortex $(3 \mathrm{~mm} \times 3 \mathrm{~mm})$ were excised from the ovary using a razor blade and pierced onto a 25-gauge needle ( 6 strips per needle). The loaded needle was transferred into a $50 \mathrm{~mL}$ conical tube of equilibration solution at $39^{\circ} \mathrm{C}$ for $5 \mathrm{~min}$. The loaded needles were then removed from the equilibration solution and transferred into a $50 \mathrm{~mL}$ conical tube of vitrification solution at $39^{\circ} \mathrm{C}$ for $5 \mathrm{~min}$. Immediately following incubation, the loaded needles were plunged into liquid nitrogen and stored for 7 days. After storage, the loaded needles were thawed in a $50 \mathrm{~mL}$ conical tube containing M199 at $39^{\circ} \mathrm{C}$ and then incubated in oocyte maturation medium for $24 \mathrm{~h}$.

\section{Examination of Follicular Development}

After thawing and incubation, the ovarian cortex samples were fixed in formalin for $48 \mathrm{~h}$ followed by incubation in deionized water for $24 \mathrm{~h}$ at room temperature. Samples were then dehydrated through an increasing concentration of ethanol solutions (80, 90, 95, and 100\% (v/v)) for 30 min each. Finally, the samples were cleared in Histo-Clear ${ }^{\circledR}$ (Electron Microscopy Sciences, Hatfield, Pennsylvania, USA) and embedded in Paraplast ${ }^{\circledR}$ (Electron Microscopy Sciences). Cross-sections $(10 \mu \mathrm{m})$ of ovarian cortex were cut using a rotary microtome and placed on albumenized slides followed by staining with hematoxylin and eosin (Electron Microscopy Sciences).

After staining, ovarian cortex cross-sections were examined using a phase-contrast microscope at $100 \times$ magnification. Follicles were classified by their stage of development based on the criteria formulated by Griffin et al. (2006): primordial (oocytes without a zona pellucida and surrounded by up to a single layer of flattened granulosa cells) (Fig. 1A), primary (oocytes surrounded by 1 layer of cuboidal granulosa cells) (Fig. 1B), preantral (oocytes with more than 1 layer of granulosa cells but no visible space between the layers) (Fig. 1C), and antral (visualization of an antral cavity) (Fig. 1D). Follicles were also assessed as being normal (Fig. 1) or damaged (follicular cell disruption, cells in the antrum, ruptured zona pellucida).

\section{Maturation of Oocytes}

After thawing and incubation, oocytes were aspirated from antral follicles ( 3 to $6 \mathrm{~mm}$ diameter) on the ovarian cortex samples. Oocytes were selected only if at least 3 layers of compact cumulus cells and a consistently dark cytoplasm were present. Selected oocytes were washed 3 times and placed into $500 \mu \mathrm{L}$ wells ( 45 to 55 oocytes per well) of maturation medium and incubated for 40 to $42 \mathrm{~h}$. After incubation, cumulus cells were removed by vortexing the oocytes in M199 supplemented with 
$0.1 \%$ hyaluronidase $(\mathrm{w} / \mathrm{v})$ for $3 \mathrm{~min}$. Intact oocytes with uniform granulated cytoplasm and an extruded polar body were washed 3 times in IVF medium and utilized in the procedures below.

\section{In Vitro Fertilization and Embryo Culture}

Frozen semen pellets from 3 different boars (International Boar Semen, Eldora, Iowa, USA) were thawed in Beltsville Thawing Solution (BTS) and centrifuged for $5 \mathrm{~min}$ at $36.3 \mathrm{~g}$. The semen was washed twice in BTS by resuspending the pellet with repeat pipetting followed by centrifugation for $5 \mathrm{~min}$ at $553 \mathrm{~g}$. The spermatozoa pellet was then resuspended in IVF medium to achieve a concentration of $2.0 \times 10^{5}$ spermatozoa per $\mathrm{mL}$ and incubated for $1 \mathrm{~h}$ before $50 \mu \mathrm{L}$ was added to each group of oocytes (30 oocytes per drop) in $50 \mu \mathrm{L}$ drops of IVF medium. After $6 \mathrm{~h}$ of IVF, the putative embryos were washed 3 times in embryo culture medium, placed (50 embryos per drop) into $100 \mu \mathrm{L}$ drops of embryo culture medium, and incubated. Embryos were analyzed for cleavage and blastocyst formation at $48 \mathrm{~h}$ and $144 \mathrm{~h}$ after IVF, respectively.

\section{Examination of In Vitro Fertilization Characteristics}

At $12 \mathrm{~h}$ after the end ofIVF, putative embryos were fixed in $4 \%(\mathrm{w} / \mathrm{v})$ paraformaldehyde in phosphatebuffered saline (PBS) for $1 \mathrm{~h}$ then permeabilized in $0.5 \%(\mathrm{v} / \mathrm{v})$ Triton $^{\mathrm{TM}} \mathrm{X}-100$ in $0.1 \%(\mathrm{w} / \mathrm{v})$ sodium citrate for $30 \mathrm{~min}$. Following permeabilization, putative embryos were stained with $1 \mu \mathrm{g} / \mathrm{mL}$ bisBenzimide $\mathrm{H} 33342$ trihydrochloride for $15 \mathrm{~min}$ at room temperature and examined using fluorescent microscopy (excitation maximum wavelength was $346 \mathrm{~nm}$ and emission maximum wavelength was $460 \mathrm{~nm}$ ). Putative embryos were assessed for spermatozoa penetration rate (oocyte containing 1 or more swollen sperm heads and/or MPN and 2 extruded polar bodies in the perivitelline space), polyspermic penetration (oocyte containing

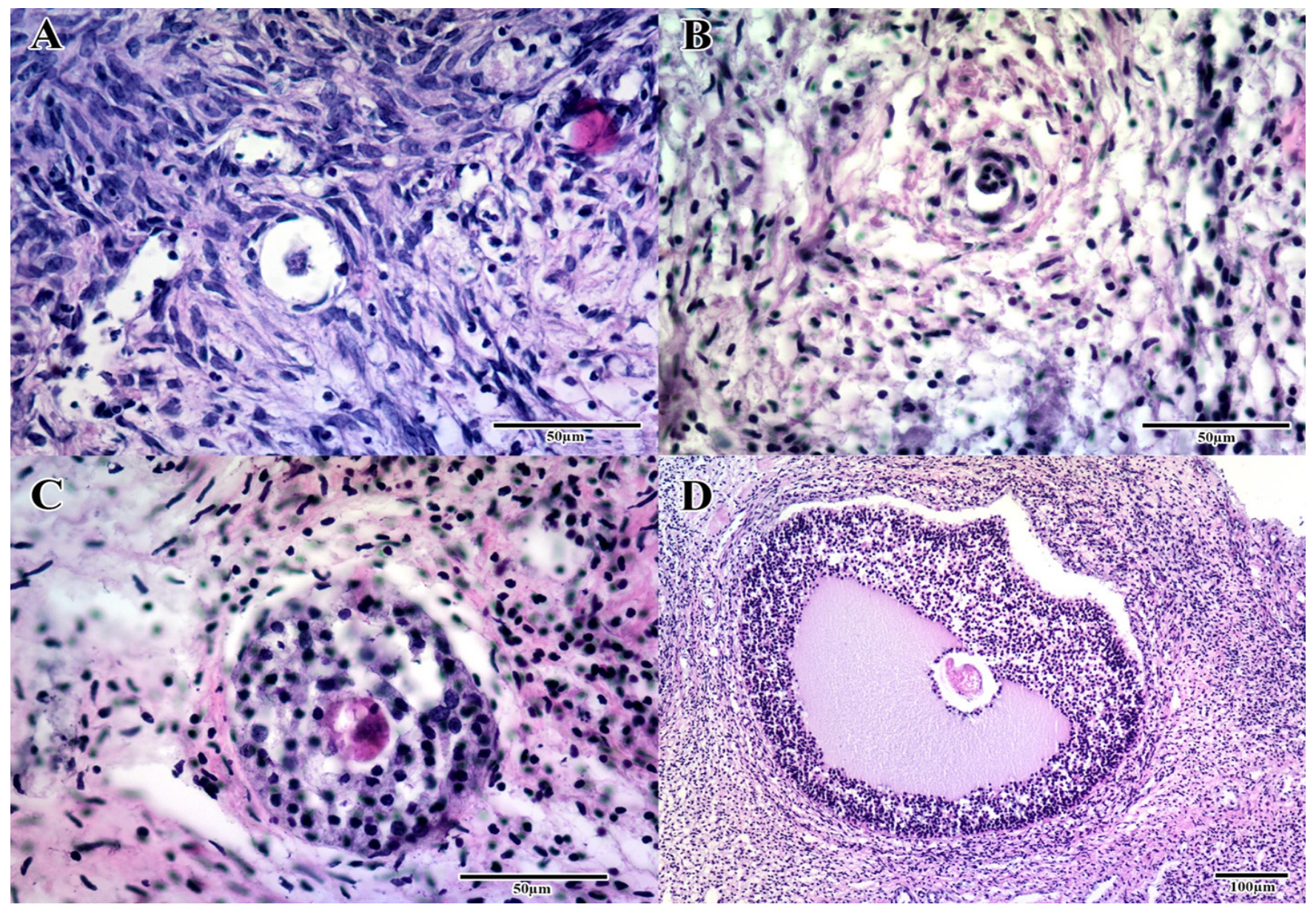

FIGURE 1. Follicular classification. The classification of follicular stages used for analysis. (A) Primordial follicles were defined as an oocyte without a zona pellucida and surrounded by up to a single layer of flattened granulosa cells. (B) Primary follicles possessed an oocyte surrounded by 1 layer of cuboidal granulosa cells. (C) Preantral follicles were oocytes with more than 1 layer of granulosa cells but no visible space between the layers. (D) Antral follicles had the presence of an antral cavity. 
more than 1 swollen sperm head and/or MPN and 2 extruded polar bodies in the perivitelline space), MPN formation (oocyte containing 1 or more MPN and 2 extruded polar bodies in the perivitelline space), and IVF efficiency (number of monospermic penetrated oocytes divided by the total number of oocytes inseminated).

\section{Experimental Design}

This experiment studied the effects of supplementing $0.5 \mathrm{mg} / \mathrm{mL}$ zinc chloride to the equilibration and vitrification media used to treat ovarian cortex tissue. After vitrification, thawing, and incubation, a portion of the cortex tissue samples were used to classify follicular development and whether they were damaged $(n=284)$.

From the remaining ovarian cortex tissue, oocytes from antral follicles were matured for 40 to $42 \mathrm{~h}$ in maturation medium and then inseminated using IVF. At $12 \mathrm{~h}$ after the end of IVF, putative embryos were evaluated for the number of oocytes penetrated, the number of polyspermic oocytes, the number of oocytes penetrated with a MPN, IVF efficiency $(n=200)$, and the number of embryos cleaved at $48 \mathrm{~h}$ post-IVF and blastocysts at $144 \mathrm{~h}$ post-IVF $(n=200)$.

\section{Statistical Analysis}

Statistical analyses were performed using the $\mathrm{IBM}^{\circledR}$ SPSS ${ }^{\circledR}$ Statistics 25.0 software package (IBM Corp., Armonk, New York, USA). Data were assessed for normality using the Kolmogorov-Smirnov test. The IVF and embryo development were not normally distributed; therefore, percentage data were arcsine transformed to obtain normally distributed data which were then analyzed by one-way ANOVA using the GLM procedure. Fixed effects included in the initial model were treatment, well, and replicate. Well and replicate effects were not significant $(p>0.05)$ and deleted from the final model. When there was a significant effect, the significance of differences was determined using Tukey adjustment for multiple comparisons. Chi-squared analysis was used to determine the significance of differences in the percentage of follicles and embryos reaching the different developmental stages for each treatment. In all analyses, two-tailed $p<0.05$ was considered significant. Results are expressed as the mean \pm standard error (SE).

\section{RESULTS}

Supplementing $0.5 \mathrm{mg} / \mathrm{mL}$ zinc chloride to the equilibrium and vitrification media increased $(p<0.05)$ the percentage of antral follicles $(16.1 \pm 2.8 \%)$ compared to no supplementation (control) $(11.6 \pm 2.2 \%)$. There were no significant differences in the percentage of primordial, primary, and preantral follicles between the control and zinc chloride supplementation treatment groups (Table 1).

Supplementing $0.5 \mathrm{mg} / \mathrm{mL}$ zinc chloride to the equilibrium and vitrification media had no effect on follicular damage after the vitrification process except zinc chloride significantly decreased $(p<0.05)$ antral follicular damage $(72.0 \pm 3.8 \%)$ compared to not supplementing zinc chloride (control) $(86.7 \pm 4.1 \%)$ (Table 2 ).

There were no statistical differences in sperm penetration rates or IVF efficiency between the treatment groups; however, the zinc chloride supplemented group had decreased $(p<0.05)$ polyspermic penetration rates and increased $(p<0.05)$ MPN formation compared to the control (Table 3).

There were no statistical differences between the treatment groups in the percentage of embryos cleaved by $48 \mathrm{~h}$ after IVF $(26.0 \pm 6.0 \%$ control vs. $30.0 \pm 6.1 \%$ zinc chloride) or percentage of blastocysts formed by $144 \mathrm{~h}$ after IVF $(14.0 \pm 5.0 \%$ control vs. $16.0 \pm 3.7 \%$ zinc chloride) .

\section{DISCUSSION}

Cryopreservation can preserve living biological tissues, either through slow-freezing or vitrification. Once cryopreserved, the living tissues are in a state of suspended animation, as water exists only in a solid state and biological reactions cease (Jain and Paulson 2006). The only imminent danger to the cryopreserved material is DNA damage due to radiation; however, when handled correctly cryopreservation extends the viability to thousands of years (Mazur 1980). The ability to cryopreserve female gametes complements assisted reproduction by extending its application to fertile women. It may be used to avoid embryo cryopreservation, avoid synchronization issues in donation cycles, delay childbearing, or preserve germ cells when faced with cancer or sterilizing therapies such as chemotherapy and radiation or extirpative surgery. 
Table 1

Effects of zinc chloride during freezing on subsequent follicular development after thawing

\begin{tabular}{llllll}
\hline \hline Treatment group $^{\dagger}$ & $\begin{array}{l}\text { Total follicles } \\
\text { counted }(\mathbf{n})\end{array}$ & $\begin{array}{l}\text { Primordial } \\
\text { follicles \% (n) }\end{array}$ & $\begin{array}{l}\text { Primary } \\
\text { follicles \% (n) }\end{array}$ & $\begin{array}{l}\text { Preantral } \\
\text { follicles \% (n) }\end{array}$ & $\begin{array}{l}\text { Antral } \\
\text { follicles \% (n) }\end{array}$ \\
\hline Control & 129 & $\begin{array}{l}62.0 \pm 3.5^{\mathrm{a}} \\
(80)\end{array}$ & $\begin{array}{l}15.5 \pm 3.1^{\mathrm{a}} \\
(20)\end{array}$ & $\begin{array}{l}10.9 \pm 4.5^{\mathrm{a}} \\
(14)\end{array}$ & $\begin{array}{l}11.6 \pm 2.2^{\mathrm{a}} \\
(15)\end{array}$ \\
& & $58.1 \pm 2.8^{\mathrm{a}}$ & $\begin{array}{l}14.2 \pm 3.4^{\mathrm{a}} \\
(22)\end{array}$ & $\begin{array}{l}11.6 \pm 4.1^{\mathrm{a}} \\
(18)\end{array}$ & $\begin{array}{l}16.1 \pm 2.8^{\mathrm{b}} \\
(25)\end{array}$ \\
$\begin{array}{l}0.5 \mathrm{mg} / \mathrm{mL} \text { zinc } \\
\text { chloride }\end{array}$ & 155 & $(90)$ & $(22)$ &
\end{tabular}

${ }^{\dagger}$ Treatment groups were no zinc chloride supplemented to ovarian tissue equilibrium and vitrification media (control) and $0.5 \mathrm{mg} / \mathrm{mL}$ zinc chloride supplemented to ovarian tissue equilibrium and vitrification media.

${ }^{\mathrm{a}, \mathrm{b}}$ Data are expressed as the means $\pm \mathrm{SE}$. Means with different superscripts, and within the same column, differ significantly $(p<0.05)$. Significant differences between columns are not comparable.

Table 2

Effects of zinc chloride during freezing on subsequent follicular damage after thawing

\begin{tabular}{llllll}
\hline \hline Treatment group $^{\dagger}$ & $\begin{array}{l}\text { All follicles } \\
\text { damaged \% (n) }\end{array}$ & $\begin{array}{l}\text { Primordial } \\
\text { follicles } \\
\text { damaged \% (n) }\end{array}$ & $\begin{array}{l}\text { Primary } \\
\text { follicles } \\
\text { damaged \% (n) }\end{array}$ & $\begin{array}{l}\text { Preantral } \\
\text { follicles } \\
\text { damaged \% (n) }\end{array}$ & $\begin{array}{l}\text { Antral } \\
\text { follicles } \\
\text { damaged \% (n) }\end{array}$ \\
\hline Control & $26.4 \pm 1.9^{\mathrm{a}}$ & $\begin{array}{l}12.5 \pm 3.5^{\mathrm{a}} \\
(34)\end{array}$ & $\begin{array}{l}25.0 \pm 2.9^{\mathrm{a}} \\
(14)\end{array}$ & $\begin{array}{l}42.9 \pm 2.1^{\mathrm{a}} \\
(5)\end{array}$ & $\begin{array}{l}86.7^{2} \pm 4.1^{\mathrm{a}} \\
(28)\end{array}$ \\
& $29.0 \pm 2.2^{\mathrm{a}}$ & $14.4 \pm 3.9^{\mathrm{a}}$ & $27.3 \pm 3.5^{\mathrm{a}}$ & $44.4 \pm 1.8^{\mathrm{a}}$ & $72.0 \pm 3.8^{\mathrm{b}}$ \\
$\begin{array}{l}0.5 \mathrm{mg} / \mathrm{mL} \text { zinc } \\
\text { chloride }\end{array}$ & $(45)$ & $(4)$ & $(4)$ & $(8)$ & $(20)$ \\
\hline
\end{tabular}

${ }^{\dagger}$ Treatment groups were no zinc chloride supplemented to ovarian tissue equilibrium and vitrification media (control) and $0.5 \mathrm{mg} / \mathrm{mL}$ zinc chloride supplemented to ovarian tissue equilibrium and vitrification media.

${ }^{\mathrm{a}, \mathrm{b}}$ Data are expressed as the means $\pm \mathrm{SE}$. Means with different superscripts, and within the same column, differ significantly $(p<0.05)$. Significant differences between columns are not comparable.

Table 3

Effects of zinc chloride during freezing on subsequent oocyte fertilization characteristics $12 \mathrm{~h}$ after fertilization

\begin{tabular}{lllll}
\hline \hline Treatment group $^{\dagger}$ & $\begin{array}{l}\text { Oocytes } \\
\text { penetrated \% (n) }\end{array}$ & $\begin{array}{l}\text { Polyspermic } \\
\text { oocytes }^{\S} \%(\mathrm{n})\end{array}$ & $\begin{array}{l}\text { Oocytes with } \\
\text { MPN }^{\S} \text { (n) }\end{array}$ & IVF efficiency \% \\
\hline Control & $78.0 \pm 6.3^{\mathrm{a}}(78)$ & $\begin{array}{l}42.3 \pm 6.3^{\mathrm{a}} \\
(33)\end{array}$ & $\begin{array}{l}47.4 \pm 5.0^{\mathrm{a}} \\
(37)\end{array}$ & $45.0 \pm 5.9^{\mathrm{a}}$ \\
& & $\begin{array}{l}30.7 \pm 3.1^{\mathrm{b}} \\
0.5 \mathrm{mg} / \mathrm{mL} \text { zinc }\end{array}$ & $\begin{array}{l}56.0 \pm 3.7^{\mathrm{b}} \\
(42)\end{array}$ & $52.0 \pm 6.6^{\mathrm{a}}$ \\
$\begin{array}{l}75.0 \pm 7.1^{\mathrm{a}}(75) \\
\text { chloride }\end{array}$ & & $(23)$ & \\
\hline
\end{tabular}

${ }^{\dagger}$ Treatment groups were no zinc chloride supplemented to ovarian tissue equilibrium and vitrification media (control) and $0.5 \mathrm{mg} / \mathrm{mL}$ zinc chloride supplemented to ovarian tissue equilibrium and vitrification media.

${ }^{\S}$ Percentage of the number of oocytes penetrated.

${ }^{\mathrm{a}, \mathrm{b}}$ Data are expressed as the means \pm SE. Means with different superscripts, and within the same column, differ significantly $(p<0.05)$. Significant differences between columns are not comparable. 
Pigs (Sus scrofa) are an ideal research model for ovarian tissue cryopreservation due to the similar genetics, organ development, and disease progression as seen in humans (Whyte and Prather 2011). Preserving ovarian tissue has advantages over single oocyte preservation: freezing the oocytes within the follicle creates a less sensitive environment compared to freezing unprotected oocytes (Oktay et al. 1997). Additionally, with tissue cryopreservation, a large number of oocytes can be frozen at once (Abedelahi et al. 2013). However, damage caused by vitrification occurs more often in ovarian tissue compared to other tissues due to the multiple cell types within the ovary tissue (Abedelahi et al. 2013).

The principal goal of successful ovarian cryopreservation is to minimize ice-crystal formation during the thawing process, since the expansion of crystals causes damage to the cell membrane and intracellular organelles (Jain and Paulson 2006). Antioxidants have been found to improve tissue preservation during the vitrification process (Dos Santos Morais et al. 2019). The presence of zinc in the vitrification medium increases follicle viability and the percentage of morphologically normal follicles in mice (Geravandi and Azadbakht 2017). Likewise, results from the current study show that supplementation of $0.5 \mathrm{mg} / \mathrm{mL}$ zinc chloride during vitrification of ovarian cortex tissue samples decreases antral follicle damage after thawing. Additionally, the oocytes obtained from the antral follicles vitrified with zinc chloride had improved rates of MPN formation and fewer occurrences of polyspermic penetration.

The changes in ovarian tissue structure as a result of vitrification may lead to follicular damage (Tian et al. 2015), such as smaller follicular diameters compared to non-vitrified follicles (Abkenar et al. 2014) and reduced oocyte viability (Gupta et al. 2010). Zinc is a standard component in most oocyte maturation media (Jeon et al. 2014), a requirement for the completion of meiosis (Bernhardt et al.2011), and essential for embryonic development (Jeon et al. 2015). The results of the current study indicate that supplementing zinc chloride to the vitrification and equilibrium media decreases damage to the antral follicle as a result of vitrification. Zinc supplementation did not significantly decrease damage in the earlier stages of follicular development, perhaps because zinc and the zinc transporters are increased and widely distributed as follicles develop (Zhong et al. 2013), hence there is no mechanism in place to transport the supplemented zinc into the cells. The findings of the current study support previous research that found supplementing zinc during vitrification increases the percentage of morphologically normal follicles in the tissue (Geravandi and Azadbakht 2017).

Vitrification affects oocyte viability by causing abnormal ROS generation, leading to an increased rate of apoptosis and early embryonic loss (Chang et al. 2019). Additionally, oocytes that undergo vitrification experience a reduced fertilization rate as a result of damage that occurred during the procedure (Hunter et al. 1995). Zinc acts as an antioxidant in 3 different mechanisms within a cell: (1) it inhibits NADPH oxidase, which when active, uses NADPH to catalyze the production of ROS in a cell; (2) it acts as a co-factor for superoxide dismutase, an enzyme that converts the ROS into hydrogen peroxide; and (3) it induces the generation of metallothionein, which acts as a scavenger of ROS (Prasad 2014). It is not surprising then, that the current study found supplementing zinc chloride to the vitrification and equilibrium media increased MPN formation and decreased instances of polyspermy during IVF. This suggested an increase in IVF success although the penetration rates and efficiencywere notaffected. Overall penetration rates could be low because cryopreservation induces zona pellucida hardening through early cortical granule release, since cryoprotectants typically increase intracellular calcium concentrations (Ghetler et al. 2006). These current findings are in agreement with those that suggest supplementing zinc in the vitrification and equilibrium media improves mouse oocyte viability (Geravandi et al. 2017).

Efficient preservation of oocytes is important to provide assisted reproductive technology options for women, improving biomedical models, and conservation of endangered species through gamete rescue (Murarka et al. 2015). Further understanding of methods to maintain oocyte and follicle viability is needed to improve the productivity of the vitrification of ovarian tissue. However, a greater understanding of how the vitrification process affects the internal mechanisms within the oocyte, and the specific role of zinc in the vitrification process, is still needed. 


\section{Conclusions}

This is the first study in pigs that considers the effects of supplementing $0.5 \mathrm{mg} / \mathrm{mL}$ zinc chloride to the equilibrium and vitrification media for ovarian cortex tissue cryopreservation. The reported results highlight that zinc chloride supplementation reduces antral follicle damage after thawing and improves IVF success by reducing polyspermic penetration rates and increasing MPN rates. These findings may be used to advance new strategies to improve the cryopreservation of female gametes.

\section{ACKNOWLEDGEMENTS}

This research was made possible by endogenous student research grants.

\section{LITERATURE CITED}

Abedelahi A, Rezaei-Tavirani M, Mohammadnejad D. 2013. Fertility preservation among the cancer patients by ovarian tissue cryopreservation, transplantation, and follicular development. Iran J Cancer Prev. 6(3):123-132.

Abkenar ZO, Ganji R, Khajehrahimi AE, Bahadori MH. 2014. Vitrification and subsequent in vitro maturation of mouse preantral follicles in presence of growth factors. Cell J. 16(3):271-278.

Agarwal A, Gupta S, Sharma RK. 2005. Role of oxidative stress in female reproduction. Reprod Biol Endocrin. 3(article no. 28$): 21 \mathrm{p}$.

https://doi.org/10.1186/1477-7827-3-28

Bernhardt ML, Kim AM, O'Halloran TV, WoodruffTK. 2011. Zinc requirement during meiosis I-meiosis II transition in mouse oocytes is independent of the MOS-MAPK pathway. Biol Reprod. 84(3):526-536.

https://doi.org/10.1095/biolreprod.110.086488

Chang H, Chen H, Zhang L, Wang Y, Xie X, Zhang Y, Quan F. 2019. Effect of oocyte vitrification on DNA damage in metaphase II oocytes and the resulting preimplantation embryos. Mol Reprod Dev. 86(11):1603-1614.

https://doi.org/10.1002/mrd.23247

Dos Santos Morais MLG, de Brito DCC, Pinto Y, Silva LM, Vizcarra DM, Silva RF, Cibin FWS, Campello CC, Alves BG, Araujo VR, da Chagas Pino F, Pessoa ODL, Figueiredo JR, Rodrigues APR. 2019. Natural antioxidants in the vitrification solution improve the ovine ovarian tissue preservation. Reprod Biol. 19(3):270-278. https://doi.org/10.1016/j.repbio.2019.07.008

Geravandi S, Azadbakht M. 2017. The presence of zinc in the mouse ovary vitrification medium: histological evaluation and follicle growth. Cryoletters. 38(2):108-118.

Geravandi S, Azadbakht M, Pourmoradi M, Nowrouzi F. 2017. Zinc supplementation of vitrification medium improves in vitro maturation and fertilization of oocytes derived from vitrified-warmed mouse ovaries. Cryobiology. 74:31-35. https://doi.org/10.1016/j.cryobiol.2016.12.007
Ghetler Y, Skutelsky E, Ben Nun I, Ben Dor L, Amihai D, Shalgi R. 2006. Human oocyte cryopreservation and the fate of cortical granules. Fertil Steril. 86(1):210-216. https://doi.org/10.1016/j.fertnstert.2005.12.061

Griffin J, Emery BR, Huang I, Peterson CM, Carrell DT. 2006. Comparative analysis of follicle morphology and oocyte diameter in four mammalian species (mouse, hamster, pig, and human). J Exp Clin Assist Reprod. 3(article no. 2):9 p. https://doi.org/10.1186/1743-1050-3-2

Gupta MK, Uhm SJ, Lee HT. 2010. Effect of vitrification and beta-mercaptoethanol on reactive oxygen species activity and in vitro development of oocytes vitrified before or after in vitro fertilization. Fertil Steril. 93(8):2602-2607. https://doi.org/10.1016/j.fertnstert.2010.01.043

Hunter JE, Fuller BJ, Bernard A, Jackson A, Shaw RW. 1995. Fertilization and early embryology: vitrification of human oocytes following minimal exposure to cryoprotectants; initial studies on fertilization and embryonic development. Hum Reprod. 10(5):1184-1188.

https://doi.org/10.1093/oxfordjournals.humrep.a136115

Jeon Y, Yoon JD, Cai L, Hwang SU, Kim E, Zheng Z, LeeE, Kim DY, Hyun SH. 2014. Supplementation of zinc on oocyte in vitro maturation improves preimplantation embryonic development in pigs. Theriogenology. 82(6):866-874. https://doi.org/10.1016/j.theriogenology.2014.06.021

Jeon Y, Yoon JD, Cai L, Hwang SU, Kim E, Lee E, Jeung EB, Hyun SH. 2015. Effect of zinc on in vitro development of porcine embryos. Theriogenology. 84(4):531-537. https://doi.org/10.1016/j.theriogenology.2015.04.006

Jain JK, Paulson RJ. 2006. Oocyte cryopreservation. Fertil Steril. 86(4):1037-1046.

https://doi.org/10.1016/j.fertnstert.2006.07.1478

Mazur P. 1980. Limits to life at low temperatures and at reduced water contents and water activities. Origins Life Evol B. 10:137-159. https://doi.org/10.1007/BF00928665

Murarka S, Mishra V, Joshi P, Sunil K. 2015. Role of zinc in reproductive biology - an overview. J Reprod Med Infertil. 2(2):1009.

Mouttham L, Comizzoli P. 2016. Presence of sucrose in the vitrification solution and exposure for longer periods of time improve post-warming follicle integrity in cat ovarian tissues. Reprod Domest Anim. 52(S2):224-229. https://doi.org/10.1111/rda.12847

Oktay K, Nugent D, Newton H, Salha O, Chatterjee P, Gosden RG. 1997. Isolation and characterization of primordial follicles from fresh and cryopreserved human ovarian tissue. Fertil Steril. 67(3):481-486. https://doi.org/10.1016/s0015-0282(97)80073-8

Prasad AS. 2014. Zinc is an antioxidant and anti-inflammatory agent: its role in human health. Front Nutr. 1:14. https://doi.org/10.3389/fnut.2014.00014

Schmidt K, Clark A, Mello A, Durfey C, Buck A, Boyd K, Whitaker BD. 2015. The effects of glucuronic acid and $\mathrm{N}$-acetyl-D-glucosamine on in vitro fertilization of porcine oocytes. Reprod Fertil Develop. 28(8):1223-1231.

https://doi.org/10.1071/RD14226 
Showell MG, Mackenzie-Proctor R, Jordan V, Hart RJ. 2017. Antioxidants for female subfertility. Cochrane Database Syst Rev. 7(article no. CD007807):51 p. https://doi.org/10.1002/14651858.CD007807.pub3

Takahashi M. 2012. Oxidative stress and redox regulation on in vitro development of mammalian embryos. J Reprod Develop. 58(1):1-9. https://doi.org/10.1262/jrd.11-138n

Tian T, Zhao G, Han D, Zhu K, Chen D, Zhang Z, Wei Z, Cao Y,Zhou P. 2015. Effects of vitrification cryopreservation on follicular morphology and stress relaxation behaviors of human ovarian tissues: sucrose versus trehalose as the nonpermeable protective agent. Hum Reprod. 30(4):877-883. https://doi.org/10.1093/humrep/dev012

Whyte JJ, Prather RS. 2011. Genetic modifications of pigs for medicine and agriculture. Mol Reprod Dev. 78(1011):879-891. https://doi.org/10.1002/mrd.21333

Yuan Y, Spate LD, Redel BK, Tian Y, Zhou J, Prather RS, Roberts RM. 2017. Quadrupling efficiency in production of genetically modified pigs through improved oocyte maturation. P Natl Acad Sci USA. 114(29):E5796-E5804. https://doi.org/10.1073/pnas.1703998114

Zhong ML, Guo C, Chi ZH, Shan ZY, Teng WP, Wang ZY. 2013. Distribution of zinc and zinc transporters in the mouse ovarian follicles and corpus luteum. Histol Histopathol. 28:1517-1527.

https://doi.org/10.14670/HH-28.1517 